\title{
Islamic culture and globalisation: Challenges and responses
}

\author{
Md. Cholem Ullah \\ Center for University Requirement Courses (CENURC) \\ International Islamic University Chittagong (IIUC), Bangladesh
}

\begin{abstract}
This paper is a humble endeavor to look at the relationship between Islam and globalisation from cultural perspective. The paper explores the nature of Islamic culture and its interaction with the west as part of the fundamental factors of how the west employ the policies against Islam in the most inhumane form. Now, western powers have been propagating against Islam. It is thus significant to analyze the role of ummah in this milieu of cultural globalisation for preparedness in shaping and constructing the course of globalisation in the coming days. This paper seeks to explain how will ummab meet challenges facing Islam as a cultural participator in globalisation where Islam is attributed with terrorism and other allegations, albeit is not Islamic at all and will never been part of the Islamic teaching and culture.Against this backdrop, Islam's future and its culture depend on Muslim ummab's ability and their uncompromising mindset- not to integrate modernity and western culture into Islam but to make the new global order that can infuse religious norms like solidarity, community and identity.
\end{abstract}

Keywords Islamic culture, Globalisation, Muslim ummah, Westernisation, Civilization

Paper type Research paper

\section{Introduction}

Allah proclaims in the holy Qur'an: "O mankind, indeed we have created you from male and female and made you peoples and tribes that you may know one another. Indeed, the most noble of you in the sight of Allah is the most righteous of you. Indeed, Allah is Knowing and Acquainted."

This Qur'anic verse makes it clear that the notion of globalisation is coherently related to the conceptual framework of Islam and Muslim ummah. ${ }^{2}$ Globalisation primarily acts to spread and exchange connectivity in ideas, cultural life, various types of political, economic, technological and all other orders across the world. It means all cultural approaches and trends of human life offer the people on this planet for being closely related to private as well as public life. The term also applies to the enhancement of any idea beyond international arena rather than the process

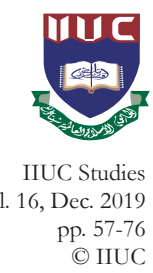

ISSN 1813-7733 
of internationalisation and westernisation. However, the present scenario of globalisation can be viewed basically with its different orders (Ahmad, 2006).

Moreover, globalisation enables us to understand the methods of multicultural dimensions with disseminating cultural life among nations. It plays a role as a framework for the re-ordering of the world. The term has also led to the fast transformation of exist cultures around the world. (Nurullah, 2008). Here Islam and globalisation are firmly tied in an equivalent position where Islamic religio-social, political and cultural ideas have been changing many conventional orders throughout the world since the early medieval era. In these cases, the incumbent duties upon Muslim ummab to have proper concepts of what are really happening with them. As the participants of globalisation, they must have the ability of judgment what are culturally useful and harmful for them. Their response to globalisation should be more positive and creative rather than staying isolated.

We now see many Europeans and Americans exert influence on globalisation or new globalisation that can be considered as merely westernisation. But Islam is reaping the benefits of globalisation through its cultural values, faith and principles with a view to establishing universal fraternity, equality and peaceful coexistence for the mankind. Consequently, Islam ignores strictly imperialism, neocolonialism or westernisation in place of globalisation. At the same time, Islam does offer its religious value, morality and ethics for a sustainable and appropriate framework for globalization (Ahmad, 2006).

Islam, thus, prescribes its moral and ideological guidelines based on its divine sources (Qur'an and Sunnab) that demonstrate the crystal-clear footsteps for the ummah so that Muslims could be a globalising force for all means of development for their worldly and perpetual phases of life. It is, hence, in the context of cultural globalisation, they must be able to respond to the challenges of westernisation in order to globalise Islam as a participator and contributor to globalisation. Dr Munawar Anees has rightly remarked that the Muslim community is now inclined to western socio-economic, political and cultural life where they are fully confined with inexplicable fatalism that stops them from employing knowledge for evolution (Anees, 2000). But Muslims are only able to accelerate the globalisation of Islam if they attempt the tracks and follow the guidelines prescribed by the guidelines of the sublime holy Qur'an and the tradition of the Prophet (peace be upon him). On the contrary, Anwar Ibrahim (Ibrahim, 1996) has destined the vision of ummah who "must be able to transcend cultural specificity (and) inhabit the realm of universal ideas."

The main objective of the study is to explore the impact of globalization 
on Islamic culture. This study is also intended to understanding the globalization and its challenges to Islamic culture and its identity; and reviewing the responses of Muslim ummah to meet the challenges in the context of westernisation. It will take an effort to incorporate scopes and roles for ummah to uphold and spread Islamic culture around the world through cultural globalization. The study also presents some observations on ummah's future cultural, socio-economic, religious and intellectual trajectories of Muslim people.

\section{Literature Review}

Primarily globalisation is defined as a process of aggregating global connectivity, incorporation and interdependence in the cultural, political, religious, social, economic, technological and all other intellectual spheres. It is a development that makes the experience of everyday life more standard everywhere in the world. But, it is regarded by the west as a springboard for social, political, economic, cultural and technological advancement. (Ahmad, 2006), (Abushouk, 2006), (Anthony, 1990), (Khaled, 2007), (Tapper, 2000). Muslim ummah is the best example of a universal community where Islam emerged as the greatest revolution in the 7 th century in the world through the process of globalisation. Muslims have made efforts to develop their traditional and religious relationship with the emerging demands of the modern world. But unfortunately, many non-western members were able to be free themselves from the colonial jurisdiction of western power or westernization. (Nurullah, 2008), (Pakeeza \& Chishti, 2012: 728) (UNAFEI, 2006). There is 57 independent Muslim nations in the world. The countries are peopled by more than 900 million Muslims. Muslims do not share similar cultural trait among themselves, but are identified as Muslims due to their same religious practice and cultural identity. (Ahmad, 2006), (Mazrui, 1998), (Hassan, 2006).

The link between globalization and religion has been addressed by objectively analyzing the positive and negative experiences and impacts on each other. It was also concluded by addressing the relationship between the two from the point of view of Islam and its culture, specifically Islamic culture also suggests suggestions that are necessary for the globalization process to bring about equality. Islam is the only cultural religion that always holds globalisation among all religious ideologies. From the 7th century, Muslims rapidly acted to spread Islam beyond Arabia to every nock and corner of the world. All modern civilisations, particularly European and American civilisations are indebted to Islam and its religious culture. Many Muslims are hesitant to allow westernisation for its technological 
advancement and modernisation, even colonialism. (Briffault, 1919), (Forid \& Khan, 2008), (Khaled, 2007), But scholars of both western and Islamic civilisations do not ignore the comprehensive coexistence between religious culture and globalisation. Islam instructs following a number of standard moralities and principles in accordance with Shariah. These principles are accommodated as the stuff of cultural globalisation, incorporating with all religions. The mutual exchange ultimately sustains the spirit of solidarity and cultural heterogeneous. (Nadwi, 1982), (Najjar, 2005), (Pakeeza \& Chishti, 2012). Main challenge for Islam is to meet cultural globalisation actively. It is not possible to appreciate globalisation without understanding the process of globalisation. Thus, the spread of the Muslim people (ummah) and the impact of globalization on religion have resulted in Islamic cultural responses to the transitions, inconsistencies and challenges that Islam faces from globalization. (Briffault, 1919), (Gholami, 2005), (Inayatullah, 2005), (Maisami, 2003), (Monshipouri, 2005), (Pakeeza \& Chishti, 2012).

Most important approach is pluralism of norms and values of all religions shedding light on mutual understanding. The Muslim ummah in the world is in a weak position when measuring collective progress of their economic, political, social, democratic, cultural and religious development and Islam is in need of understanding of the world's view. (Abushouk, 2006), (Armstrong, 2002), (Azzouzi, 2013), (Hourani, 1992). Muslims do require a renaissance of faith. For attaining the renaissance, Muslims must exert Tawhid (oneness in Allah) in their hearts, says Al-Qur'an. All duties of ummah are mainly centered by five basic practices of Islam. These include praying five times a day or salah, obligatory charity or zakah, fasting in Ramadan or saum, spiritual journey to Mecca for pilgrimage or hajj. Muslims should follow Islamic social and cultural life rather than other life and societies. The role of the ummab in this milieu of cultural globalisation can help shape the course of globalisation. (Ahmad, 2006), (Nadwi, 1982).

Muslims must regain their lost glories in the development of civilisation and moral identity. Western media intentionally propagates Islam as a threat to life and society. Despite, the recent scenario in the world is reflecting a huge number of western people's overwhelmingly conversion into Islam. London, Paris and New York will become cities of Islam in the coming decades. Islamic culture is incumbent to meet the challenge and resolve this clash between Islam and westernisation. This is the successive result of cultural globalisation of Islam. (Ahmad, 2006), (Esposito, 2016), (Forid \& Khan, 2008). (Inayatullah, 2005), (Hassan, 2006), (Hassan, 2003). Islamic scholars emphasize on acquiring knowledge for Muslim ummah meeting all types of challenges to Islam. Without intellectual advancement, Muslims will 
not be capable to transmit and accelerate cultural excellence of Islam against westernisation. (Ibrahim, 1991), (Forid \& Khan, 2008), (Hassan, 2006), (Inayatullah, 2005). IT and social media networks have connected more than 1.2 billion Muslims across the world. Traditional cultural unity of Muslim states is certainly needed to propagate the sublime essence of Islamic cultures. Rich Muslim countries should participate in the development of poor Muslim states. Commercial ties and free trade agreement (FTA) must be set off among each other. OIC can play a pivotal role with the establishment of sustainable democratic cultures. (Hassan, 2003). (Hassan, 2006). (Forid \& Khan, 2008: 98), (Esposito, 2016).

But comprehensive analytical approaches on Islamic culture to meet exiting challenges of modern globalisation were not taken in these works. So, in this paper, Islam based cultural and religious basic challenges have been analyzed in context of Islam as globalising force. Considering the present trend of globalization and culture, duties and responsibilities of Muslim ummah have been explored that must be performed by the Muslims to uphold the religious and cultural values; to establish themselves as the best nation among all nations of the world.

\section{Methodology}

This study is followed the research based on qualitative approach. Since a qualitative research is an unstructured, this article is designed based on desk and library-oriented research. To find out the challenges of globalization that met by Muslims and Islamic culture in the world, the research focused on available published literatures, journals, newspapers, magazines, works and speeches of Muslim scholars and thinkers that are related to Islamic culture and globalization. The texts of the Qur'an and Hadiths are used as primary sources of data for analysis the study and its concept.

\section{Globalisation and Islam}

Globalisation can be defined as a process of aggregating global connectivity, incorporation and interdependence in the cultural, political, religious, social, economic, technological and all other intellectual spheres beyond the geographical boundaries across countries and territories (Khaled, 2007). Hence, globalisation always brings out changes and links connectivity among different parts in the world. The basic changes are visible in the physical transportation with various communicational means coupled with numerous dimensions of information technology. So, Giddens Anthony, remarks (Anthony, 1990) it as the rapid development in the trend of information technology, communication, transport and infrastructural development by which the world's remotest parts are now easily reachable, no matter how 
distant they are. According to the Encyclopedia Britannica, globalisation is a process that makes the experience of everyday life more standard everywhere in the world. For example, local economies are incorporated into the world economy through the process of globalization (Tapper, 2000). Even globalization can be defined based on different ideological backgrounds. Ahmed Ibrahim Abushouk proved that definition of globalization is to be categorized into five varied and broad forms of ideologies as internationalisation, liberalisation, universalisation, westernization and deterritorialisation (Abushouk, 2006: 487-489).

Basically, one can argue that the above-mentioned each definition relating to globalisation explores the term from a certain standpoint, but finally all the collective meanings accumulate that today's globalisation emerging from the Anglo-Saxon model ultimately gives the phenomenon a complete shape. Our planet is now treated as a global village mainly because of the driving and guiding forces through squeezing distance, cultural homogeneity, minimising the significance of political borders and tempering national sovereignty (Abushouk, 2006: 489).

Alternatively, in recent years, many scholars have succeeded in remarking westernisation as the origin of globalisation and the western culture is being globalised as the components of globalisation. Here westernisation and modernisation are verified as globalisation, but it is neither an individual development nor a separate process like globalisation. Appreciating globalisation as westernisation and modernisation creates an appeal and draws attention to its origin that consisted of destructive colonial expansion of European imperialism. Therefore, no need to mention that western power is to intend monopolising modern process of globalisation and establish the trend of developments with various policies. So, globalisation is regarded by the west as a springboard for social, political, economic, cultural and technological advancement. On the eve of westernisation or the post-World War II decades, many non-western members were able to be free themselves from the colonial jurisdiction of western power or westernisation. But unfortunately, they failed to achieve a strong position of economic development, modern technological advancement and cultural freedom from the supremacy of western imperialism (Pakeeza \& Chishti, 2012: 728).

In fact, now Muslims have a great tendency to follow the western life and culture without thinking its affects in future (Nurullah, 2008). In appreciation of such western influence on globalisation, a good number of Muslims in the modern world also believe that globalisation is being ultimately dominated by the west and the countries that are influential in the 
western circles like Japan and some states of South-East Asian territories (Pakeeza \& Chishti, 2012: 728). These dominated states are positioned in such a way that no scope is there to debate in this regard. Actually, leading industrial states promote the technological and administrative developments as the focal point of global impact. So, it is also reflected in the economic and commercial policies that are exercised by major developed states. But historically, the Muslim ummab is the best example of a universal community where Islam emerged as the greatest revolution in the 7th century in the world through the process of globalisation. The people of Arab Peninsula, Asia, Africa and Europe revered and fostered with the Islamic culture. Since then, Islamic civilisation emerged as the most beneficial and humanitarian by the process of globalisation over all conventional civilisations, cultures and ideas in the contemporary world (UNAFEI, 2006).

It is perceived that the comparative changes in the global order are not visible in Islam and its cultural life like the western world in any respect of modernity. Since the beginning of the 19th century, Muslims have made efforts to develop their traditional and religious relationship with the emerging demands of the modern world (such as religious, political, economic and social demands). The trend was observed from pre-modern to post-modern time. But these remarkable changes of the modern world are deeply related to westernization or the western values, ideas and institutions (UNAFEI, 2006). So, ummah reacted to modernisation and took the efforts to reform Islamic cultures maintaining a space from secularism. But in their contributions to reforms of Islamic cultures, they were divisioned into Islamic modernists, traditionalists and conservatives.

For the flourishing of different civilizations as well as cultures over many centuries in the history of the world, the term globalisation can also be applicable to the expansion and assimilation of cultures around the world, predominantly right through religious and ideological trends. Generally, every act and aspect of human life is part of culture rather than evolution in the context of globalisation or Islamic standpoint. Islamic culture depicts itself in its unique approach to dealing with each individual as part of ummah. The term ummah is used for the people of the Islamic community having emotional, moral and social ties that are stabilised with the personal relationships over time (Pakeeza \& Chishti, 2012). To consolidate interstate bonds, there are 57 independent Muslim nations in the world. The countries are peopled by more than 900 million Muslims in addition to an estimated 400 million more Muslims settled throughout the rest of the world.

The spread of Islam has played a pivotal role in the well-being of all aspects of temporal life of the peoples in addition to its contribution to the 
development of spiritual prosperity in many societies in the context of cultural globalisation in the world. Therefore, in the common global scenario, it is seen that the civilised people are closely related to the basics of Islamic doctrine, ethics, values, morals, laws and customs (UNAFEI, 2006). It is also seen that Muslims do not share similar cultural trait among themselves, but they are identified as Muslims due to their same religious practice and cultural identity (Nurullah, 2008). In spite of some cultural variations among Muslims in the world, Islam is the fastest-growing religion and the second-largest faith in the earth. As a result, the Muslim populace is growing everywhere in the world towards cultural and religious globalisation. Rationally, this index is a substantial issue related to the basic world orders of the time (Ahmad, 2006).

Against this backdrop, Muslims among the nations meet with the critical challenges of how to face and adjust globalisation with the new global tides. The challenges are also being posed to face modernity where Muslim nations are concerned to establish a linkage between Islamic values with secularism, democracy, westernisation and liberalism. But expectations are rising from ummah that the challenges should be for the betterment of Islamic culture with singular influence over all other cultures. At the same time, the linkage does not degrade or pale Islam in the face of cultural globalisation and westernisation as well.

\section{Responses of Islam as a Globalising Force}

Now many conversions and changes are made to cultural globalisation in the question of opposing or accepting religion as basic elements of globalisation where Islam has significantly consolidated its stance in the religio-social, cultural and political situation in the world (Nadwi, 1982. p.80). It is said that the new global order is espousing a secular-based idea and religion responds to a global debate in respect of modernisation as well as technological development in any respect. In so far as religion is concerned, religion and religious culture can be very active force in the unification of the global community over some shared values and norms that are not in disagreed with the central thought and organisation of the universal order, rather those combine and unite the globalization process (Pakeeza \& Chishti, 2012).

The consequence of this response, the trend in the clash of civilisation has paved the way for debating on religion what resulted in effective dialogues between western and Islam for cementing the gap from both sides with a view to achieving the supremacy of religion. Using the principles of religion, such supremacy can be applied as the main goal of globalisation. In fact, Islam is the only cultural religion that always holds globalisation among all religious ideologies. From the 7 th century, Muslims reawakened. They rapidly 
acted to spread Islam beyond Arabia to every nock and corner of the world, making contribution to the human destiny. It is the unique influence of Islamic globalisation that all modern civilisations, particularly European and American civilisations, are indebted to Islam and its religious culture. Robert Briffault has rightly stated that it is not possible to remark any single field of European revival which is not owing to Islam (Briffault, 1919: 190).

When the question usually arises about the religion based globalisation in the modern world, culture or religion is needed to appreciate whether it will be able to include all spaces of globalisation or not. However, contemporary scholars of both western and Islamic civilisations do not ignore the comprehensive coexistence between religious culture and globalisation. But many Muslims are hesitant to allow westernisation for its technological advancement and modernisation, even colonialism. Here, a citizen of the global village would be more tolerant considering all ethos but common morality and ethics will be exposed by all religions, which inspire moral and fair qualities in the personal and public life of global culture. Through this process of exchanging culture (mutual exchange of culture), the universal platform of cultural globalisation is emerged. Religion can, thus, able to turn all diverse communities into one platform in the world sharing religious values and principles with each other.

This mutual exchange ultimately sustains the spirit of solidarity and cultural heterogeneity over diversification of unethical and immoral elements in religious sanctions to others. These rational meetings of cultures by cultural globalisation are mostly eligible for promoting the space of peaceful coexistence in the global world. In this status of cultural correlation, Islam indeed instructs following a number of standard moralities and principles in accordance with Shariah ${ }^{3}$. These principles are accommodated as the stuff of cultural globalisation, incorporating with all religions as the process of globalisation.

In the holy Qur'an, Prophet Muhammad (peace be upon him) is declared and sent by Allah as the last and the final messenger of Islam, as the maker of peace among all races on earth. The final messenger Muhammad (peace be upon him) emerged on earth when the entire world slipped into the morass of criminalities. His advent gave the humanity a sacred and blessed life prescribed by divine rules. As it is declared in the holy Qur'an: "And we have not sent you, [O Muhammad], except as a mercy to the worlds." Reputed Islamic scholar Abul Hasan Ali really marked Islam and its final messenger (peace be upon him) as:

--"There is absolutely no need for a new religion, a new canonical law or a new set of moral teachings for Muslims. Like the sun, Islam was, is 
and will never be old. The apostleship of Prophet Muhammad (peace be upon him) is endowed with the quality of timelessness. No other apostle of Allah is to be raised now. His religion is everlasting, his teachings are immortal." (Nadwi, 1982: 188).

Initially, we see one of the mandatory ordains of Islam for the people to cooperate with and be helpful to each other in accordance with goodness and virtue; and not being cooperative to sins and malice. Prophet Muhammad ${ }^{5}$ (peace be upon him) strongly asserted this principle from root levels to everywhere in the society beyond the question whether your neighbour is Muslim or non-Muslim. Undoubtedly, this significant principle can be followed from local to the international arena by the followers of Islam. Thus, a neighbouring or an adjacent country of a Muslim state will be verified through its economic and cultural relationship with Islamic world (Maisami, 2003).

However, now the focal point for Islam or the main challenge for the ummah is to meet cultural globalisation actively. Even they are to know the trend and characteristic of socio-economic and cultural development of modern world. And historically, it is not possible to appreciate any aspect of development without understanding the process of globalisation on the standpoint of comprehensive socio-economic, political and cultural pluralisation (Gholami, 2005). Thus, this factor brings many challenges for Muslim ummah from the beginning of the $21^{\text {st }}$ century, and they are necessarily required to take the stance owing to maintaining a balance between cultural integrity and religious identity. On the other hand, Muslim world should have the ability to adapt the changes proceeded by globalisation with maintaining cultural integrities of Islam. To meet the challenges of globalisation, Muslim world does not grip the problems, changing its cultural identity in cultural globalisation. Muslims must develop their religious belief and culture according to Shariah and fortify their communal integrity as well (Monshipouri, 2005).

\section{Challenges in Globalising Islam}

The challenges of Islamic culture as a global force lie in what roles of the Muslims play in the globalised world by understanding the world's view of Islam and the view of Islam about the world vice versa. But unfortunately, the present situation of the Muslim ummah in the world is appreciated weak position when measuring collective progress of their economic, political, social, democratic, cultural and religious development. For the reason that, Karen Armstrong remarked "It is important to note that the Muslim weakness at the end of the eighteenth century coincided with the rise of an entirely 
different type of civilisation in the west, and this time the Muslim world would find it far more difficult to meet the challenge." (Armstrong, 2002: 141).

Monaim El Azzouzi just pointed the challenge of Islam to globalisation: "The challenges of globalisation to religion link automatically to the challenges of religion to globalisation.” (Azzouzi, 2013). Being a traditional approach, religion affects global culture; many communities individually or collectively take religion as an element of apprehension and conflict to meet the needs of cultural globalisation. In this respect, it is viewed that religion leads intervention in the cultural globalisation in general sense and ultimately the impacts of values regarding religion on global societies cause conflict among religious communities.

But in some cases, religion-based culture and values of globalisation may be homogeneous. Nonetheless, most important approach to globalisation is pluralism of norms and values of all religions shedding light on mutual understanding among all religions beyond controversy. Regrettably, Islam is misinterpreted and misunderstood disgracefully as a propagator of terrorism by some western media, even by some western governments. They also go a further length to look for many evil means to impute a terrorist logo to Islam as a religion of extremists (Abushouk, 2006).

From this point of view, how will Islamic culture be actively an existing part of cultural globalization? Despite being a part of globalisation, Islam is highlighted as terrorism along with other blames put on Islamic people. Now the challenge for ummah is that how Islam and its culture will be rectification from such blames. It is very common scenario, in fact, no nation along with its culture will be received by others, if that nation is accused of terrorism or any other violence against humanity at any region throughout the world. Despite of above being weaknesses of ummah today, it can be said all is not bad news. There are certain positive developments and there is definitely light at the end of the tunnel for the Muslim world. For why, it is easy to prescribe the role of the ummah in this milieu of cultural globalisation for preparedness in shaping and constructing the course of globalisation in upcoming days (Ahmad, 2006).

First of all the ummah must keep their faith in Islam. At first, they will have to regenerate themselves with only faith. Abul Hasan Ali remarked appropriately the fact:

--"But Muslims do require a renaissance of faith. One cannot face new hazards and meet new challenges with a dilapidated faith and unauthorised practices. A decaying building cannot stand through a flood. One must have a living, glowing and unbending faith in the cause one seeks to uphold. If the Islamic world aspires to inject a new 
enthusiasm and a new life into humanity, to give it the courage to resist and revert the torrents of materialism and religious disbelief, it will first have to produce that enthusiasm and that life in itself" (Nadwi, 1982: 188).

For attaining the faith, Muslims must exert Tawhid (oneness in Allah) in their hearts so that they can take an opportunity to practise Tawbid. This is a very unique and fundamental value of Islam and this is evidently important and a driving force for cultural globalisation of the ummab. One of the significant meanings of Tawhid is everything has come from Allah and ultimately will return to Him. It does mean Allah is only the Alfa and alone Allah is the Omega. This eschatological truth leads a Muslim to be conscious of his origin and ultimate return, just since his departure or death is a gateway from the world to hereafter (Forid \& Khan, 2008). So, the term is truly governed with the moral supremacy over the factual ethics and over collective integration of spiritual and temporal life. Its prime commitment is to establish justice, beneficence and compassion (al-adl wal ehsan) for all mankind, shura or consultation as a legislative process of making decisions in every affair of the state (Ahmad, 2006). Obviously, these values shape a framework for cultural globalisation of Islam.

Upholding the spirit of Tawhid is only possible if Muslims have the gritty determination to uphold ordains of the holy Quran and Sunnah. Consequently, they will follow Islamic social and cultural life rather than other life and societies. Moreover, the ummab should take hold of all possible opportunities which are conducive to following Islam. At the same time, they will endeavour to overcome all hurdles and weaknesses among themselves. On the other hand, they should pave the way for effective cultural dialogues with western sides and constructive dialogues with the rest of the world. Allah says in the Qur'an: “Thus we have appointed you a middle nation, that ye may be witnesses against mankind, and that the messenger may be a witness against you" 6

Muslims must have their vision and mission in flourishing cultural objectives based on Islam. They will have to regain their lost glories in the development of civilisation and moral identity. Before globalisation took its root, all duties of ummah are mainly centered by five basic practices of Islamknown as the five pillars of Islam (declaration of faith or sabadah, praying five times a day or salah, obligatory charity or zakah, fasting in Ramadan or saum, spiritual journey to Mecca for pilgrimage or hajj)- and some other obligatory beliefs. Traditional practices of these beliefs among ummah were presented everywhere by many Muslims as evidence before the world that entire culture of all Muslim societies were assimilated with Islamic culture of Arab what territory is recognized as the birthplace of Islam. Universally this cultural 
conversion of all Muslims was considered an integral part of Mohammed's (peace be upon him) social and religious mission (Hassan, 2003).

There is, therefore, no alternative for the ummah but to revive their lost glories in tying all mankind into a single nationhood based on the Charter of Madinah. ${ }^{7}$ Here, the ummah have no way to dishonour the dignities and rights of non-Muslims whose rights are also prescribed in Islam. Also, the ummah should not allow so-called modernism but take an avowed aim with determination to recover the glorious past of Islamic culture and pave a superb future over the post-western era (Hassan, 2006).

It must be a matter of great recognition that those who submit themselves to Islam theoretically and practically will at least never commit or involve in any subversive acts like terrorism, extremism or fanaticism. Actually, cultural values and ethos of Islam are accustomed with the safeguard of humanities for both temporal and perpetual life. The recent scenario in the world is reflecting a huge number of western people's conversion into Islam. This is the successive result of cultural globalisation of Islam, even if the influential western propagandists are firmly standing against Islam. Still, the western media plays the role to politicise the Islamophobia in the state affairs throughout the world from west to east. Somehow this media intentionally propagates Islam as a threat to life and society (Inayatullah, 2005). In fact, if a follower of any religion is misguided and does not follow the instructions and jurisdiction of his/her religion, the very religion should not be charged for their followers those showing laxity in religion.

From any perspective, it is true that in the rapid march of technology in the $21^{\text {st }}$ century, the Muslim ummah is standing in the middle of multiple challenges, but none is more formidable than the issue of how to make a balance between cultural integrity and religious identity of Islam. On the contrary, the ummah must have the approach of enduring the changes associated with a globalising world. So, in the age of cultural exchange, Muslim ummah must have a future plan. Otherwise, they will decline without a clear vision of their future (Inayatullah, 2005). But the weakness of the ummah, in the perspective of global civilisation, is associated with the rise of various cultures in the west. Islamic culture is incumbent to meet the challenge and resolve this clash between Islam and westernisation. In the circumstances, the future of Islam and its culture depends on the ummah's ability to remain constant with an uncompromised trend in the time of fusing modernity into western culture. At any cost, they are required to comply with the principles of Islam in exchanging Islamic culture with all other cultures in view of westernisation and relatively branding Islamic culture in the arena of cultural globalisation. 
It appears that the consequent responses of globalisation of Islam can be reflected in European territories by the rapidly increasing Islamic population. As a result, this ultimate rapid growth of Islam will form London, Paris and New York as cities of Islam like modern Mecca, Istanbul and Cairo in the coming decades of the $21^{\text {st }}$ century (Esposito, 2016). It is well known to all that Islam is the fastest-growing religion on earth and the Muslim community presented Islam as a global phenomenon across the national boundaries. Certainly, this rapid growing of Islamic followers clearly marks the process of cultural and religious globalisation of Islam which is emerging as a vital force of globalisation (Esposito, 2016).

Among new challenges in globalisation, Muslim ummah recapture moral and practical responsibilities wherein they will take part in solving global warming, addressing environmental pollution and ecological disasters, and taking sustainable action against terrorism. (Inayatullah, 2005). They should accordingly follow the Qur'anic jurisprudence in the establishment of justice, equity and exemplification of pure morality of Islam. These desired roles of ummah will only be possible by acquainting with knowledge and doing research (Forid \& Khan, 2008: 85-89). All Muslim scholars put emphasize on acquiring knowledge for Muslim ummah meeting all types of challenges to Islam and its cultural globalisation. And definitely the looming challenge for ummah is intellectual, not religious or ideological. Due to ummah's intellectual stagnation, now they are certainly backwarded in scientific and modern technological developments (Hassan, 2006). So, the most significant of all is a commitment to literacy for everybody. Our Prophet (peace be upon on him) asserted on gaining knowledge and stated as "The seeking of knowledge is obligatory for every Muslim." Without intellectual advancement, Muslims will not be capable to transmit and accelerate cultural excellence of Islam against westernisation, western media and its propaganda. As Ibrahim writes: "Only with access to appropriate education can Ummah consciousness take room and make possible the Ummah of tomorrow as a personification of the pristine morality of Islamic endowed with creative, constructive, critical thought" (Ibrahim, 1991: 309).

It is true that modern information technology (IT) and social media networks have connected more than 1.2 billion Muslims across the world through globalisation. And this connectivity marks the fast spread of Islamic culture as the indication of Islam as a globalising force towards western peripheries and also promotes the scale of modernisation from both sides-from the side of Islamic culture and from western culture. Thus, Muslim world holds some impetus standpoints for consolidating Islamic cultures globally. ANM Wahidur Rahman pinpointed the need for the 
flowering of IT from Muslim ummah. He said, "If Muslims are to survive as a nation as an ummah, they will have to devote their full energies and capacities to cope with the western technological progress (but not at the expense of their own faith)." (Forid \& Khan, 2008: 98). Thus by using IT, ummah need to go forward overcoming local and national issues and making global context based analysis so that they can understand the main features of social life and emerging religio-cultural and political trend in contemporary Muslim societies (Hassan, 2006).

Hence, Islamic culture will have also be excelled in forming Islam as the driving force of cultural globalisation where Islam and all other cultures will prevail on a common ground. This ground will ensure potentiality of collective progress in globalisation. It has also the scope to tie the unique mutual understanding between modernisation and cultural globalisation. This is significantly needed on account of pluralisation of religion-based all cultural identities (Esposito, 2016). Basically, conventional cultural unity of Muslim states is certainly needed to propagate the sublime essence of Islamic cultures on the face of westernisation. Since some contrasts of religious and cultural aspects are appeared in the perception of ummab's life and society, it is the only way of flourishing Islamic culture over all other cultures by integrating various cultures into one platform (Hassan, 2003).

On economic front, all Muslims must have the uncompromising tendency in the question of the unity of the ummah. In this case, the rich Muslim countries should participate in the development of poor Muslim states without following illegal policies like high rate of interest and bribe. Besides the policy, commercial ties and free trade agreement (FTA) must be set off among each other with all possibilities, including the adaptation of sustainable development goals.

To make Islamic culture as the main influential factor of cultural globalisation, all Muslim states should gradually accord to the road of economic development exclusively. In this respect, some strong economic organisations should be formed with a view to developing them as powerful economic entities globally along with strengthening all financial indexes comparing with the developed countries in the world. To this end, the OIC (Organisation of Islamic Cooperation) can play a pivotal role with the establishment of sustainable democratic cultures, cultural diversification and economic advancements among its Muslim affiliations. Furthermore, the organisation must maintain strong vigilance so that national cultures of Muslim states must not contradict with the main source of Islamic culture, the holy Qur'an and Sunnah of the Prophet (peace be upon him).

The impact of globalisation on Islam was a hotly debated issue after the 
1/11 terrorist attack in America. Over the years, globalisation started to make Muslims aware of Islam and Islamic culture with social diversities on the one hand by the propaganda of western media and mass communication tools like newspaper, book and magazine. But on the other, globalisation also allowed western disruptive military to penetrate many Muslim countries. But the ultimate consequences of the force of globalisation were colonial expansion along with the emerging nationalist movements that served fragmentation of Islamic world with completion of political and economic interests of the United States and its allies. Nevertheless, sharing same Islamic culture and beliefs of ummah across Muslim world is being brought by globalisation as a sense of greater sentiment. It is also meant that this consciousness or sentiment attributes the Muslim world's unity to a high-toned sense of belonging to the believers of Islam across the world (Hassan, 2003). But these westernizations are spreading Islam in the western world and identifying it to be the exemplary global culture along with its superiority of socio-economic and political ideologies over all conventional cultures. Islam is now the fastest-growing religious culture in the west.

\section{Conclusion}

The Muslim ummah historically gained their religious and cultural ascendancy across the world through the process of globalisation. In all considerations, Islam has become an indispensable component of the globalisation process as a universal code of life. As usual, Islam and globalisation are inextricably linked and they are knitted in the same thread as the Islamic religious doctrines, provisions and prayers speak for the entire population of the globe. Islam stipulates that a practising Muslim's duty is to convey the messages of Islam to other Muslims and non-Muslims as well. This process facilitates Islamisation and globalisation of the preaching of Islam and its rich culture across the world. A Muslim can achieve the two ultimate goals of the worldly peace and after-world purgation through becoming a part of globalising Islamic culture. It is, therefore, to be noted that no Muslim can be a perfect believer of Islam without his or her participation in the process of globalising Islamic culture.

This academic discourse fully clarifies that the globalisation of western culture is all pervasive than that of Islamic culture. This backwardness of the Muslim ummab is largely due to their sluggishness and also because of the pernicious influence of the western culture on Islamic culture. Ummab across the world are thus paying for it and they are now facing multiple challenges in globalising their rich Islamic culture and tradition. These challenges can also be faced in the light of the holy Qur'an and Hadith, the key sources of 
the Islamic culture. And then only Islam will get superiority over all existing religious cultures in society and the Muslim ummab will secure the right status as the greatest among all the nations globally.

Thus, globalisation is necessarily required to develop mutual understanding of other cultures and values among all human beings for establishment of a universal cultural platform removing discrimination and aggression. In the process of cultural globalisation and mutual dialogues, the leaders of religious communities together with political leaders should be responsible for ensuring a peaceful world. Therefore, the cultural globalisation of Islam brings a big challenge for Muslim ummah. They show a serious concern over the influence of westernisation and modernisation on Islamic culture and they are also worried regarding this cultural clout and leverage which may endanger the faith and progress of Islam. Moreover, Muslims have been facing allegations from the western world where Islam has consistently been propagated as the source of radicalism, extremism and terrorism.

The first and foremost challenge among others facing the ummab is that the regeneration of Islamic identity. So, the ummah must achieve all the qualities prerequisite to be the best ummah or nation. In holy Qur'an, the qualities are described as: "You are the best ummah (nation/people) raised up for mankind, enjoining what is right, forbidding what is wrong and believing in God."

To attain the supreme position of Islamic culture over all other religious cultures in the world, the ummah must grasp their roots- the Qur'an and Sunnab. Muslims should realise the real causes of their decline and backwardness and they must awake for their revival. Internally, the Muslim world will have to bring a regeneration of practising Islam. Islam and its culture can only thrive through becoming more cautious of the spiritual and moral revival of humanity. Muslims have to regroup themselves and stand against the negative projection of Islam by the western media and their propaganda. At the same time, the ummah must be outspoken and vocal against terrorism, extremism and suicide killing. They have no alternative but to revive the lost glories, they have to endeavour to gain the supreme authority over the western world through cultivating knowledge. (Forid \& Khan, 2008).

Taking all things into active consideration, the ummah must be protected and duly preserved from the adverse impact of the aggressive western entertainment and unhealthy cultural practice. The resource-rich and industrialised countries of the Muslim world should setup healthy entertainment facilities in compliance with Islam culture. Apart from these major attempts, all the countries of the Muslim world and their leaders should adopt standard strategies and pragmatic policies in view of reaching their defining goals. They must initiate changing their foreign policies for the 
rest of the world and making a strong public opinion to reduce the prejudices and misunderstanding against Muslims and Islam.

Fostering such an ambiance may go a long way to help Muslims overcome the ongoing challenges they are facing over the years. They must maintain a strong political identity as the followers of a religion whose adherents account for one of the largest numbers of human beings on this planet Earth. The present state of the Muslim ummah is rather disenchanting. The Muslims should seize these opportunities only if they seriously strive to overcome their weaknesses and drawbacks. If the Muslims pursue this mission diligently and with perseverance, the promise of Allah (SWT) is very clear: "Faint not, nor grieve, for ye will overcome them if ye are (indeed) believers." 10

\section{Notes}

1. Al-Qur'an,Surah Al- Hu jurat:13, 49:13

2. Arabic word "ummah" means "community" or "nation". In the context of Islam, it is used to mean the diasporas or "community of believers" and thus the whole Muslim world. (For details http://islamic-dictionary.tumblr.com). The word ummah is used for people of Islamic Community having emotional, moral, social ties that are stabilized with the personal relationships as well continuation over time. In recent times, the concept of ummah is achieving a global nature as Islam is a global community.

3. Shariah is the commands, prohibition, guidance and principles that Allah (SWT) has addressed to mankind pertaining to their conduct in the world and salvation in the next. Thus the term refers to the legal system of Islam that is a set of divine principles governing the whole worldly and perpetual life of Muslims. (Mohammad Hashm Kamali, Shari'ah Law: An Introduction, Oneworld Publication, Oxford, UK, 2008, p-14.)

4. Al-Quran, Surah Al Anbiyah: 107, 21:107.

5. Al-Quran, Surah AlMa'idab: 02, 5:02.

6. Al-Qur'an, Surab-al-Imran: 143, 2: 143

7. It is the first written constitution in history of the mankind and history of the civilization of the world. Constitution of Medina (the wathiqat al-Madina) is a document reportedly drawn up by the Prophet Muhammad (d. 11/632), upon his migration from Mecca to Medina. The document establishes rights and obligations among the Ansar (Helpers) of Medina, the Muhajirun (Emigrants) who left Mecca with the Prophet, and the Jewish tribes of Medina as they embarked upon a new journey of co-existence and cooperation in the nascent Muslim polity founded in Medina. The only documentation of the Constitution, however, exists in literary references by 
historians living centuries after the document's supposed creation. http://www.anveremon.com/publications/reflections-on-the-constitu.pdf 8. Al-Tirmidhi, Hadith: n.74.

9. Al-Quran, Surah-al Imran: 3. 3:110.

10. Al-Quran, Surah-al Imran: 3. 3:139.

\section{References}

Abushouk, A. I. (2006). Globalization and Muslim identity challenges and prospects. The Muslim World, 96(3), 487-505.

Ahmad, K. (2006). Globalization: Challenges and prospects for Muslims. Policy Perspectives, 1-11.

Ahmad, K. (1995). Islamic resurgence: Challenges, directions and future perspectives. A roundtable with Prof. Khurshid Ahmad. Institute of Policy Studies.

Anees, M. A. (2000). The future of Islam: Tie up your camel. Journal of Futures Studies, 4(2), 131-135.

Anthony, G. (1990). The consequences of modernity. Cambridge, UK.

Armstrong, K. (2007). Islam: A short history. Modern Library.

Azzouzi, E. M. (2013). Religion and globalisation: Benefits and challenges. Morocco World News. Retrieved from https: / /www.moroccoworldnews.com/2013/01/75121/religion-and-gl obalisation-benefits-and-challenges /

Briffault, R. (1919). The making of humanity. London: Allen \& Unwin.

Esposito, J. (2016). John Esposito on Islam and religious pluralism featuring LVideo file]. $\quad$ Retrieved from https: / / www.youtube.com/watch?v=81SFGqsBxK4

Forid, A., \& Khan N. A. (2008). 21st century challenges for the global Muslim community, knowledge, development and revival: Selected oriental perspectives. Dhaka, Bangladesh: Renaissance Foundation.

Gholami, K. (2005). Intercultural challenges in the space of globalization: How Muslims react to the global flows. (Essay Assignment for course: New media, communication and peace in the global knowledge society), Retrieved f $\quad r \quad o r m$ http:/ / www.mlab.uiah.fi/ kavetiso/tsure/ essays/Globalization.pdf

Hourani, A. (1992). Islam in European thought. Cambridge: Cambridge University Press.

Hassan, R. (2003). Globalization's challenge to Islam. Yale Center for the Study of Globalization. Retrieved from https://yaleglobal.yale.edu/content/globalizations-challenge-islam

Hassan, R. (2006). Globalisation's challenge to the Islamic Ummah. Asian Journal of Social Science, 34(2), 311-323. 
Ibrahim, A. (1991). The ummah and tomorrow's world. Futures, 23(3), 302-310. DOI.org/10.1016/0016-3287(91)90143-P

Ibrahim, A. (1996). The Asian renaissance. Selangor, Times Books International (Quoted in Sohail, I. (1997) A Dialogue of Civilizations. New Renaissance, $7(22), 39$.

Inayatullah, S. (2005). Islamic civilization in Globalization. From Islamic Futures to a Postwestern Civilization [Blog post]. Retrieved from https:// nawaat.org/portail/en/

Khaled, M. (2007). Globalization and religion. Paper presented at Conference on Globalisation, Conflict and The Experience of Localities. Rome: Italy.

Maisami, M. (2003). Islam and Globalization Fountain. 43. Retrieved from https://fountainmagazine.com/2003/issue-43-july-september-2003/Is lam-and-Globalization

Mazrui, A. A. (1998). Globalization: Homogenization or Hegemonization. American Journal of Islamic Social Sciences, 15(3), 1.

Monshipouri, M. (2005). Identity and human rights in the age of globalization: Emerging challenges in the Muslim World. Zaman Online. Retrieved fro https://www.globalpolicy.org/component/content/article/162/27639. html

Nadwi, A. H. A. (1982). Islam and The World. Lucknow, India: Academy of Islamic Research \& Publication.

Najjar, F. (2005). The Arabs, Islam and Globalization. Middle East Policy, 12(3), 91.

Nurullah, A. S. (2008). Globalisation as a challenge to Islamic cultural identity. International Journal of Interdisciplinary Social Sciences, 3(6), 45-52.

Pakeeza, S., \& Chishti, A. A. (2012). Globalization and religion: Islamic perspective. Academic Research International, 2(3), 724.

Tapper, H. (2000). The potential risks of the local in the global information society. Journal of Social Pbilosophy, 31(4), 524-534.

United Nations Asia and Far East Institute (UNAFEI). (2006). Islam, Globalization and Counter Terrorism, Resource Metarial Series no. 71, for the prevention of crime and the treatment of offenders. Retrieved from http://www.unafeei.or.jp/english/pdf/RS_No71/No71_00All.pdf.

\section{Corresponding author}

Md. Cholem Ullah can be contacted at: forhad314@gmail.com 